Number Theory 



\section{Number Theory}

Proceedings of the Turku Symposium on Number Theory in Memory of Kustaa Inkeri May 31-June 4, 1999

\section{Editors}

Matti Jutila and Tauno Metsänkylä

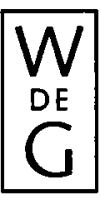

Walter de Gruyter · Berlin · New York 2001 


$\begin{array}{ll}\text { Editors } & \\ \text { Tauno Metsänkylä } & \text { Matti Jutila } \\ \text { Department of Mathematics } & \text { Department of Mathematics } \\ \text { University of Turku } & \text { University of Turku } \\ \text { 20014 Turku } & \text { 20014 Turku } \\ \text { Finland } & \text { Finland }\end{array}$

Mathematics Subject Classification 2000:

11-06

(0) Printed on acid-free paper which falls within the guidelines of the

ANSI to ensure permanence and durability.

Library of Congress - Cataloging-in-Publication Data

Turku Symposium on Number Theory (1999: Turku, Finland)

Number theory : proceedings of the Turku Symposium on Number Theory in memory of Kustaa Inkeri, May 31-June 4, 1999 / editors, Matti Jutila and Tauno Metsänkylä.

p. $\mathrm{cm}$.

ISBN 3110164817 (alk. paper)

1. Number theory - Congresses. I. Jutila, M. (Matti) II. Metsänkylä, Tauno. III. Title.

QA241 .T85 1999

$512^{\prime} .7-\mathrm{dc} 21$

00-065759

Die Deutsche Bibliothek - Cataloging-in-Publication Data

Number theory : proceedings of the Turku Symposium on Number Theory in Memory of Kustaa Inkeri, May 31 - June 4, 1999 / ed. Matti Jutila and Tauno Metsänkylä. - Berlin ; New York : de Gruyter, 2001

ISBN 3-11-016481-7

(C) Copyright 2001 by Walter de Gruyter GmbH \& Co. KG, 10785 Berlin, Germany. All rights reserved, including those of translation into foreign languages. No part of this book may be reproduced or transmitted in any form or by any means, electronic or mechanical, including photocopy, recording or any information storage and retrieval system, without permission in writing from the publisher.

Printed in Germany.

Typeset using the authors' $T_{E} X$ files: I. Zimmermann, Freiburg.

Printing: WB-Druck GmbH \& Co., Rieden/Allgäu. Binding: Lüderitz \& Bauer-GmbH, Berlin.

Cover design: Thomas Bonnie, Hamburg. 